\title{
Resistance to late leaf spot and rust diseases in ICRISAT's mini core collection of peanut (Arachis hypogaea L.)
}

\author{
H. Sudini ${ }^{1}$ - Hari D. Upadhyaya ${ }^{1,2,3}$ - S. V. Reddy ${ }^{1}$ - U. Naga Mangala ${ }^{1}$ A. Rathore $^{1}$. \\ K. Vijay Krishna Kumar ${ }^{1}$
}

Received: 11 May 2015 / Accepted: 19 July 2015 /Published online: 25 July 2015

(C) Australasian Plant Pathology Society Inc. 2015

\begin{abstract}
Late leaf spot (LLS) (Phaeoisariopsis personata) and rust (Puccinia arachidis) are major foliar diseases of peanut causing significant losses worldwide. Identification and infusion of resistance into peanut cultivars is important in the management of these diseases. The present study therefore aimed at screening the peanut mini core collection to identify potential sources of resistance to these diseases. Two separate field experiments were conducted for screening LLS and rust under artificial epiphytotic conditions during rainy seasons of 2012 and 2013 at ICRISAT, Patancheru, India. The trials were laid in a randomized complete block design on beds with three replications. Data on LLS and rust disease severities were collected using 1 to 9 scales at 75, 90 and 105 days after sowing (DAS), and pod yields were recorded at harvest. Results indicate significant variations among accessions for LLS and rust resistance. Mean of 2 years study revealed that 53 accessions were moderately resistant (MR), 86 accessions were susceptible (S) and 45 accessions were highly susceptible (HS) to LLS. For rust disease, 10 accessions were resistant (R), 115 accessions were with 'MR' reaction and 59 accessions with susceptible (S) reaction. Six superior accessions in terms of combined disease resistance and yield (ICGs 4389, $6993,11426,4746,6022,11088)$ were selected and the disease progress curves, for each, were generated. Highest yields
\end{abstract}

H. Sudini

h.sudini@cgiar.org

1 International Crops Research Institute for the Semi-Arid Tropics, Patancheru 502324, India

2 Department of Agronomy, Kansas State University, Manhattan, KS 66506, USA

3 UWA Institute of Agriculture, University of Western Australia, Crawley, WA 6009, Australia were recorded with ICG 11426 in LLS and rust plots. Overall, our results indicate that these six accessions can be potential sources of LLS and rust resistance.

Keywords Peanut $\cdot$ Mini core collection $\cdot$ Host plant resistance $\cdot$ Late leaf spot $\cdot$ Rust

\section{Introduction}

Peanut (Groundnut; Arachis hypogaea L.) is an important annual food legume crop grown in many tropical and subtropical countries of the world. Of various biotic stresses affecting peanut production, foliar diseases such as late leaf spot (LLS) caused by Phaeoisariopsis personata (Berk. \& M.A. Curtis) Van Arx and rust, caused by Puccinia arachidis Speg. are economically significant (Grichar et al. 1998; Subrahmanyam et al. 1980). Significant pod yield losses have been reported for each of these diseases especially under favorable conditions. For example, up to $80 \%$ of the pod losses are reported due to LLS (Grichar et al. 1998; Miller et al. 1990; McDonald et al. 1985). However, yield losses vary with the type of cultivar and management practices followed (Kornegay et al. 1980; Smith and Littrell 1980). Besides direct seed losses, seed size and seed weight are also reduced thereby affecting the seed quality (Souta 1912; Arthur 1929) and oil content (Gupta et al. 1988). Initially, LLS produces small chlorotic lesions, which later turn dark brown or black. The conidiophores and conidia are produced in concentric rings on the lower surface of the leaf. Severe LLS infection results in considerable defoliation (Harrison 1969). Rust disease outbreaks have previously been reported from Asia and Africa (Mehan et al. 1994) with substantial yield losses (Felix and Ricaud 1977; Subrahmanyam et al. 1980, 1985). On an average, the losses due to peanut rust alone are estimated to be in the range 
of 50 to $70 \%$ (Subrahmanyam et al. 1985). Time of incidence of rust has a direct bearing on yield losses. It is estimated that rust infestation on the crop at flowering, pegging, pre-podforming, and mid-pod-forming stages resulted in yield losses of $49,41,31$ and $18 \%$ respectively (Zhou et al. 1980). Previous research at ICRISAT, India indicated that rust disease causes yield losses to a tune of $50 \%$ (Subrahmanyam and McDonald 1983). The rust pathogen produces orange uredinial pustules on the lower leaf surfaces that rupture to expose the reddish brown urediniospores. Rust infection also results in leaf necrosis and total leaf drying (Mehan et al. 1994). Both LLS and rust together usually account for more than $50 \%$ yield losses (Subrahmanyam et al. 1989; Waliyar 1991; Savary and Van Santen 1992). These diseases collectively reduce the green leaf area available for photosynthesis and stimulate leaflet abscission leading to extensive defoliation (McDonald et al. 1985). They also affect the seed quality and fodder value of the plants (Gupta et al. 1987).

Often, these foliar diseases are managed through use of chemical fungicides as sprays (Natrajan 1984; Biswas and Singh 2005). Other management practices in the developing countries include seed treatment with non-conventional chemicals (Maiti et al. 2005), cultural practices by adjusting sowing times (Naidu and Vasanthi 1995), and through use of biological control agents (Kishore and Pande 2005) and botanicals (Hossain and Hossain 2013). Multiple applications of chemical fungicides offer quick and effective remedy for these diseases. For example, in developed countries like USA, fungicidal sprays every 2 weeks, beginning at 30 to 35 days after sowing (DAS) and continuing throughout the crop season for LLS and rust diseases is practiced for disease control (Shokes et al. 1982; Culbreath et al. 2002; Augusto and Brenneman 2011). However, under rainfed conditions, application of fungicides is not economical especially in the semi-arid tropics where crop yields are uncertain, farmers are resource poor and the crop productivity is low (Gibbons 1980). Besides, their use has several concerns such as environmental safety and scope for development of fungicide-tolerant strains of pathogen (Clark et al. 1974; Littrell 1974).

Identification of resistance to both LLS and rust, and incorporation of resistance into adapted cultivars, is a viable option without any additional input cost for managing these foliar diseases (Pensuk et al. 2003). The most recent reports on rust and LLS resistant genotypes date back to Cook (1972), Porter et al. (1982); Subrahmanyam et al. (1980, 1989). Similarly, several studies reported the rate-reducing resistance as a viable strategy for identifying improved resistance to LLS (Aquino et al. 1995; Abdou et al. 1974; Chiteka et al. 1988; Gorbet et al. 1990; Kornegay et al. 1980; Pixeley et al. 1990). However, for precise identification of resistant sources, knowledge on components and mechanisms of resistance are the prerequisites for successful breeding programs. Though earlier studies have identified several genotypes for foliar disease resistance (Waliyar et al. 1993; Anderson et al. 1993; Mehan et al. 1996; Singh et al. 1997), high degree of resistance to these diseases are not available. Moreover, differential field reaction of recently released peanut cultivars to these diseases is another problem. For example, the peanut cultivar "Southern Runner", released by the University of Florida, USA; is found to be promising and with improved resistance to LLS (Gorbet et al. 1987). On the other hand, highly susceptible reaction is observed in the recently released Thai cultivars, "Tainan 9" and "Lampang" for both LLS and rust diseases (Pensuk et al. 2003).

Plant genetic resources are being used in breeding programs, mainly as sources of resistance to pests and diseases (Knauft and Gorbet 1989). Screening of peanut mini core lines is an important aspect for identifying promising donors to biotic and abiotic stresses. These mini core collections with diverse agronomic characters are widely used for infusing genetic diversity in plant breeding programs (Upadhyaya et al. 2010). Holbrook and Dong (2005) demonstrated that the developed peanut mini core from US germplasm collection could be used for enhancing the efficiency in identifying desirable traits in the larger core and entire collection. For example, molecular characterization studies of US peanut mini core collection indicated that 39 accessions from spanish, valencia, runner market types were potentially resistant to Sclerotinia blight disease (Chamberlin et al. 2010). Similarly, partial resistance to tomato spotted wilt virus (TSWV) was identified in peanut by screening core collection (Anderson et al. 1996). In view of the frequent breakdown of foliar disease resistance as in wheat rust, our studies on identification of resistance sources to these LLS and rust diseases assume significance. For example, in wheat, the breakdown of the $\mathrm{Yr} 17$ resistance gene was reported in cultivars to yellow rust disease caused by Puccinia striiformis f.sp. tritici (Bayles et al. 2000; El-Jarroudi et al. 2011). Therefore, our objective was to evaluate the peanut mini core collection for resistance to LLS and rust diseases and identify new sources of resistance. Our present studies form the first comprehensive report on field evaluation and resistance levels among ICRISAT's mini core collection against LLS and rust diseases.

\section{Materials and Methods}

\section{Genotypes}

The peanut mini core collection consisting of 184 accessions (Upadhyaya et al. 2002) was developed based on morphological and agronomic traits from 1,704 entries of the core collection of peanut, representing 14,310 accessions available in the ICRISAT gene bank (Upadhyaya et al. 2003). These accessions are comprised of 37 fastigiata, 58 vulgaris, 85 hypogaea, two peruviana, and one each of aequitoriana, 
Table 1 Variance components due to genotypes $\left(\sigma^{2} \mathrm{~g}\right)$ and genotype $\mathrm{x}$ environment $\left(\sigma^{2}\right.$ g.e) for late leaf spot (LLS) and rust severity in the peanut mini core collection evaluated at ICRISAT, Patancheru, India during rainy seasons of 2012 and 2013

\begin{tabular}{lllllllll}
\hline Covariance Parameter & \multicolumn{2}{l}{ Late Leaf Spot } & & \multicolumn{2}{l}{ Rust } \\
\cline { 2 - 3 } & 2012 & 2013 & Pooled & & 2012 & 2013 & Pooled \\
\hline Environment $\left(\sigma^{2} \mathrm{e}\right)$ & - & - & $0.12^{\mathrm{NS}}$ & - & - & $0.002^{\mathrm{NS}}$ \\
Genotype $\left(\sigma^{2} \mathrm{~g}\right)$ & $1.47^{* *}$ & $1.13^{* *}$ & $1.24^{* *}$ & & $0.84^{* *}$ & $0.67^{* *}$ & $0.7^{* *}$ \\
Genotype $\times$ Environment $\left(\sigma^{2} \mathrm{~g}^{*} \mathrm{e}\right)$ & - & - & & $0.05^{* *}$ & & - & - & $0.06^{* *}$ \\
\hline
\end{tabular}

** Significant at Prob $<0.01$

NS Non-significant at Prob $>=0.05$ and hirsuta. The trial also included four released cultivars Gangapuri (fastigiata), ICGS 44 (vulgaris), ICGS 76 (hypogaea) and M 13 (hypogaea) for comparison. Gangapuri and M 13 are Indian cultivars, whereas ICGS 44 (ICGV 87128, PI 537112) (Nigam et al. 1990) and ICGS 76 (ICGV 87141, PI 546372) (Nigam et al. 1991) are ICRISAT-bred high-yielding cultivars released in India (Upadhyaya 2005). Three cultivars were used as standard checks: ICGV 00068 for LLS resistance, ICGV 00064 for rust resistance, and TMV 2 as susceptible check for both LLS and rust.

\section{Field evaluation of genotypes against late leaf spot (LLS) and rust diseases}

Two individual experiments on LLS and rust were laid out in two separate fields during rainy seasons of 2012 and 2013 at ICRISAT, Patancheru, India. A total of 186 accessions (184 mini core plus two standard checks) were screened for the LLS and rust experiments. The trials were laid out in a randomized complete block design (RCBD) on 20 June during both years with three replications on broad bed furrows. The size of the beds was $4.0 \mathrm{~m} \times 1.5 \mathrm{~m}$ and the mean planting density was 26.7 plants $/ \mathrm{m}^{2}$. Altogether, there were 80 plants/

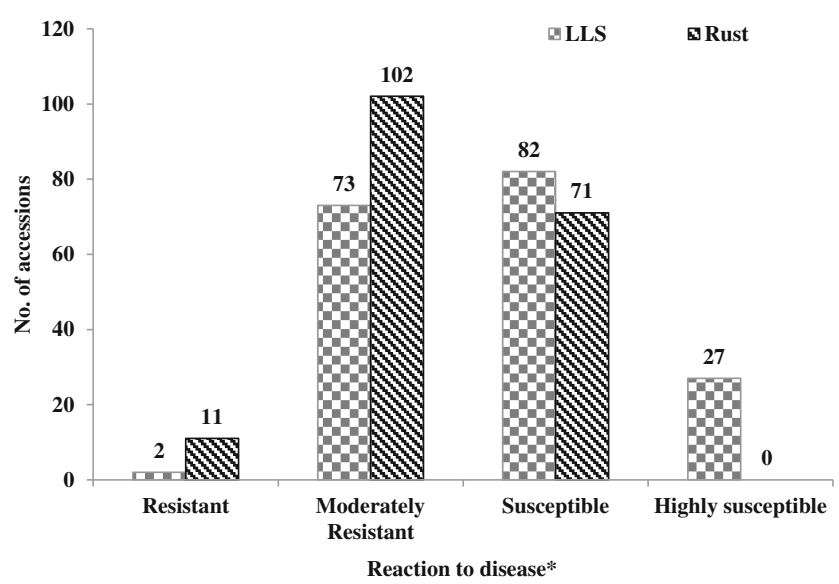

Fig. 1 Differential reaction of peanut mini core accessions to late leaf spot (LLS) and rust diseases during rainy season of 2012 at ICRISAT, Patancheru, India replication for each accession, spread in two rows, and there were four rows for each bed. Precaution was taken to ensure uniform and proper depth of planting $(5 \mathrm{~cm})$. Standard agronomic and cultural practices were followed during the cropping season. Infector row method was followed by sowing one bed (4 rows) of TMV 2 (susceptible to LLS and rust) for every four beds of test materials. In LLS experimental plots, a preventative spray with tridemorph $80 \%$ EC (Calixin) at $1.0 \mathrm{ml}$ per liter of water was given from 50 DAS at fortnight intervals on need basis to prevent rust infection. Similarly, in rust experimental plots, carbendazim $50 \% \mathrm{WP}$ (Bavistin) at $1.5 \mathrm{~g}$ per liter of water was sprayed as a preventative measure from 50 DAS at 15 days interval to prevent LLS incidence.

For artificial inoculation of these foliar pathogens, urediniospores of rust and conidia of LLS pathogens were collected separately using a cyclone spore collector (Fischer scientific co., USA) from naturally infected leaf lesions of the susceptible cultivar TMV 2 and inocula were stored at $-20 \mathrm{C}$. Ten days before planting of the test material in the field, the peanut cultivar TMV 2, susceptible to both diseases, were planted in poly bags in the greenhouse to multiply the inoculum. Thirty five

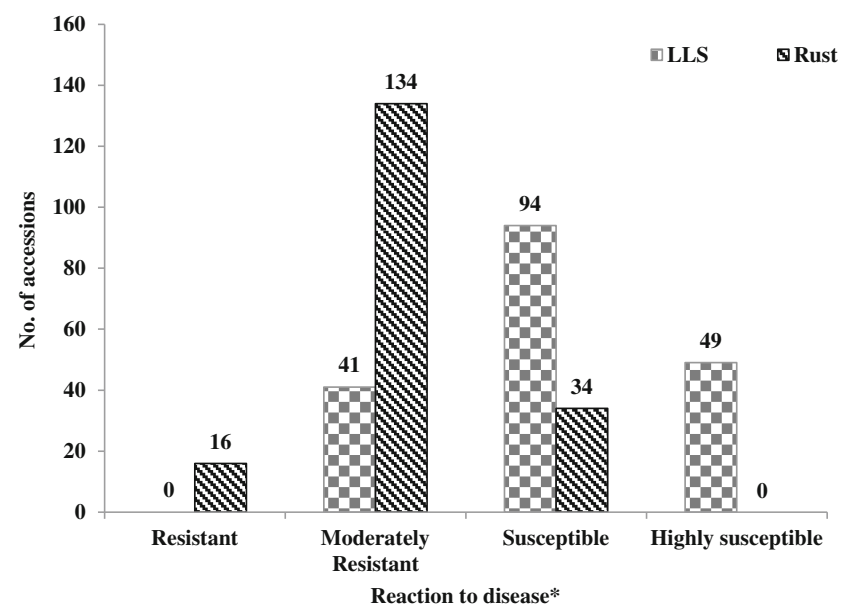

Fig. 2 Differential reaction of peanut mini core accessions to late leaf spot (LLS) and rust diseases during rainy season of 2013 at ICRISAT, Patancheru, India 
Table 2 Performance of peanut mini core collection against rust and LLS diseases based on field studies during rainy season of 2012 and 2013 at ICRISAT, Patancheru, India

\begin{tabular}{|c|c|c|}
\hline Reaction & Disease & No. of Accessions \& Details* \\
\hline \multirow[t]{3}{*}{ Resistant } & Rust & $\begin{array}{l}10 \text { accessions } \\
\text { (ICGs } 11426,11088,4389,6022,6993,2857,4746,15419,6402,6766)\end{array}$ \\
\hline & LLS & Nil \\
\hline & $\begin{array}{l}\text { Rust and } \\
\text { LLS }\end{array}$ & Nil \\
\hline \multirow[t]{3}{*}{$\begin{array}{l}\text { Moderately } \\
\text { Resistant }\end{array}$} & Rust & $\begin{array}{l}115 \text { accessions } \\
\text { (ICG’s } 14127,5051,6646,7153,12276,12625,2925,9961,10036,111,2381,4343,4527,10479,12000,14466,3053, \\
\text { 5891, 6813, 862, 928, 11457, 163, 2772, 2773, 2777, 4412, 4538, 513, 76, 8285, 8490, 9037, 9666, 9842, 11109, } \\
13723,13787,1668,2511,3027,7243,875,9777,5827,12370,4156,5663,721,13099,14008,14475,6913,9905, \\
\text { 10185, 12672, 15042, 15190, 3992, 5286, 5662, 6667, 14523, 188, 5745, 8760, 11862, 14482, 14705, 4598, 4998, } \\
\text { 6892, 334, 118, 5016, 5327, 6057, 12189, 12682, 6703, 7000, 7969, 13856, 3343, 3673, 3681, 5494, 6263, 8106, } \\
\text { 1137, 1274, 3102, 10566, 11651, 14118, 15287, 15309, 5475, 6201, 7190, 10384, 10554, 11219, 11855, 12921, } \\
13982,14106,14985,442,7181,8083,9157,9418,9809)\end{array}$ \\
\hline & LLS & $\begin{array}{l}53 \text { accessions } \\
\text { (ICG’s } 11426,12625,13787,4412,513,9842,11109,8760,10479,11457,12000,12370,2772,6022,6993,928, \\
\quad 10185,14008,163,2777,2857,4343,4389,4527,5051,532,6913,721,76,8490,9037,9905,9961,111,12276, \\
12672,13723,14475,2773,5286,875,9777,14466,3053,5663,5891,7243,15419,11219,3992,4598,6813,7153)\end{array}$ \\
\hline & $\begin{array}{l}\text { Rust and } \\
\text { LLS }\end{array}$ & $\begin{array}{l}47 \text { accessions } \\
\text { (ICG’s } 12625,13787,4412,513,9842,11109,8760,10479,11457,12000,12370,2772,928,10185,14008,163,2777 \text {, } \\
\quad 4343,4527,5051,532,6913,721,76,8490,9037,9905,9961,111,1227,12672,13723,14475,2773,5286,875, \\
\text { 9777, 14466, 3053, 5663, 5891, 7243, 11219, 3992, 4598, 6813, 7153) }\end{array}$ \\
\hline \multirow[t]{3}{*}{ Susceptible } & Rust & $\begin{array}{l}59 \text { accessions } \\
\text { (ICG's } 10474,10566,1142,115,11651,13982,14630,1973,332,5221,6201,6263,6375,8083,8517,9809,11249 \text {, } \\
\quad 1711,2019,3421,36,3746,4684,6888,1137,7963,10890,11687,12879,15287,2106,4543,5195,5236,5494, \\
\quad 5779,6654,7906,9507,12988,1519,3584,4729,4729,81,8567)\end{array}$ \\
\hline & LLS & $\begin{array}{l}86 \text { accessions } \\
\text { (ICG's } 14482,1668,2925,4156,4746,5016,6057,6667,6766,8285,862,9666,2511,3027,4538,4998,7000,15190, \\
\quad 2381,11862,14705,5662,6892,13099,5745,6646,5327,10036,14523,14127,15042,5475,5827,6402,11088, \\
\quad 11515,442,9249,11855,12682,3102,334,4955,10384,188,7190,11144,4750,118,12189,14106,14118,1415, \\
\text { 15309, 3343, 3673, 434, 10554, 13491, 14710, 297, 397, 6703, 8106, 10092, 11322, 13603, 1399, 14985, 3240, } \\
\quad 7181,9157,9315,3775,5609,6407,1274,12921,13856,13858,9418,12697,3681,4670,4911,7969)\end{array}$ \\
\hline & $\begin{array}{l}\text { Rust and } \\
\text { LLS }\end{array}$ & $\begin{array}{l}25 \text { accessions } \\
\text { (ICG’s 13491, 13858, 1399, 3240, 36, 3775, 434, 4750, 4911, 4955, 9315, 11144, 11322, 14710, 297, 4670, 5609, } \\
\quad 10092,11515,397,6407,9249,13603,1415,12697)\end{array}$ \\
\hline \multirow{3}{*}{$\begin{array}{l}\text { Highly } \\
\text { susceptible }\end{array}$} & Rust & Nil \\
\hline & LLS & $\begin{array}{l}45 \text { accessions } \\
\text { (ICG’s } 10474,10566,1142,115,11651,13982,14630,1973,332,5221,6201,6263,6375,8083,8517,9809,11249 \text {, } \\
\quad 1711,2019,3421,36,3746,4684,6888,1137,7963,10890,11687,12879,15287,2106,4543,5195,5236,5494, \\
\quad 5779,6654,7906,9507,12988,1519,3584,4729,81,8567)\end{array}$ \\
\hline & $\begin{array}{l}\text { Rust and } \\
\text { LLS }\end{array}$ & Nil \\
\hline
\end{tabular}

*Six accessions (ICG's 11426, 2857, 4389, 6022, 6993 and 15419) showed resistant to rust and moderately resistant to LLS

*Accessions are categorized based on the mean resistance/susceptible reaction to rust and LLS diseases on a 1-9 scale where Resistant $(\mathrm{R})=1-3$; Moderately resistant $(M R)=4-5$; Susceptible $(S)=6-7$; Highly susceptible $(H S)=8-9$ disease severity rating scale

days-old "TMV 2" seedlings raised in the greenhouse were inoculated separately by spraying with urediniospores of rust and conidia of LLS at $5 \times$ $10^{4} \mathrm{ml}^{-1}$. The non-ionic detergent, Tween 20 was added to the spore solution as a surfactant at the rate of $0.05 \%$ of the spore solution. Water was sprinkled in and around the inoculated plants in the polybags and the plants were covered with polyethylene sheet during the nights for 7 days to maintain high humidity (95\%).
Severe rust and LLS developed in 2 weeks and the plants were transplanted as infector rows in respective experimental fields. When the test materials were around 50-days-old, rust and LLS infected plants in polybags were transplanted in the infector and spreader rows in the two separate trials. At 50 DAS, both conidia of LLS and urediniospores of rust were sprayed at a concentration of $5 \times 10^{4}$ spores $\mathrm{ml}^{-1}$ in the respective trials. To promote disease development, sprinkler 


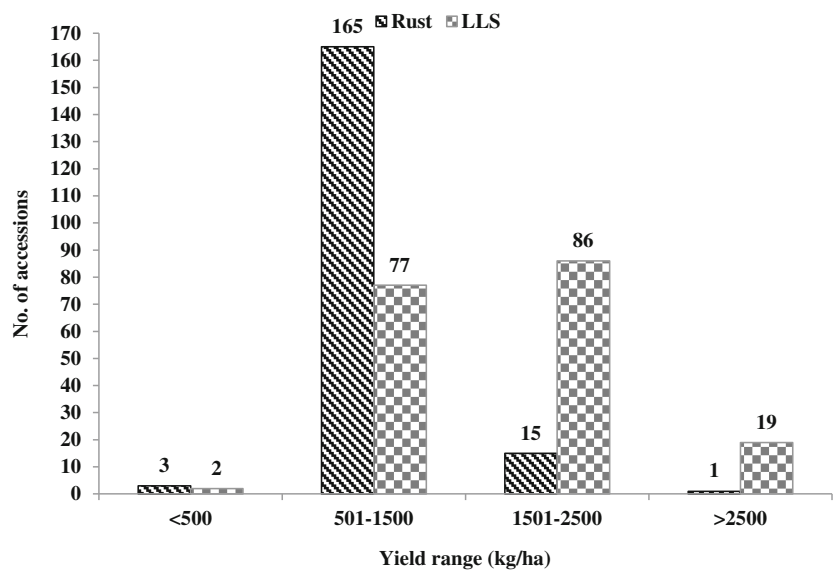

Fig. 3 Frequency distribution of peanut mini core accessions showing mean differential yields during rainy seasons of 2012 and 2013 in late leaf spot and rust infested fields at ICRISAT, Patancheru, India

irrigation was provided to the trials daily on rain free days for $30 \mathrm{~min} /$ day for $1 \mathrm{month}$ from the day of field inoculation with the pathogen.

\section{Data collection}

Data on disease severity (LLS and rust) were collected from each plot, per replication, separately in the randomized experimental blocks during 2012 and 2013. Observations on rust and LLS severity were recorded at 75, 90 and 105 DAS. For recording disease severities, 10 plants from each row were selected at random and a total of 20 plants were assessed per accession. Pod yields were recorded for each of the accessions per replication.

The disease severities for LLS and rust were measured on a 1 to 9 point field scale (Subrahmanyam et al. 1995). The disease severities corresponding to the rust and LLS scores are $1=0 \% ; 2=1-5 \% ; 3=6-10 ; 4=11-20 \% ; 5=21-30 \%$; $6=31-40 \% ; 6=31-40 \% ; 7=41-60 \% ; 8=61-80 \%$ and $9=$ $81-100 \%$. Based on the severities, the accessions were differentiated as resistant (score of $<3$ ); moderately resistant (score of 4 and 5); susceptible (score of 6 and 7); and highly susceptible (score of 8 and 9).

Accessions with lowest severity ratings for LLS and rust during 2012 and 2013 were selected for evaluating the disease progress at 75, 90 and 105 DAS were compared with that of resistant and susceptible checks. Pod yields were recorded by harvesting each accession per replication. For harvesting, plants from the entire plot were uprooted by hand and brought to the threshing floor, stripped off, and then dried prior to yield assessment. Pod yields for the selected accessions were compared with that of resistant and susceptible checks in respective experimental plots.

\section{Statistical analysis}

For each LLS and rust diseases scores, combined and year wise analysis of variance was carried out by using SAS Mixed procedure (SAS V9.3) and variance components were estimated for year (environment), genotype and genotype*environment $\left(\mathrm{g}^{*} \mathrm{e}\right)$ effects (SAS Institute Inc 2013). Best Linear Unbiased Predictors were estimated for genotypes. The performance of mini core accessions in terms of yield was analyzed and categorized. The influence of these foliar disease severities on yield was determined by comparing the yields of moderately resistant (LLS) and resistant accessions (rust) with that of resistant cultivars, ICGV 00068 and ICGV 00064 respectively.

Table 3 Field reaction of six selected peanut mini core accessions against late leaf spot (LLS) and rust diseases during rainy seasons of 2012 and 2013 at ICRISAT, Patancheru, India

\begin{tabular}{|c|c|c|c|c|c|c|}
\hline \multirow[t]{2}{*}{ Genotype } & \multicolumn{3}{|c|}{ Late leaf spot disease severity* } & \multicolumn{3}{|c|}{ Rust disease severity* } \\
\hline & 2012 & 2013 & Pooled & 2012 & 2013 & Pooled \\
\hline ICG 4389 & 4.7 & 5.3 & 5.0 & 3.0 & 3.0 & 3.0 \\
\hline ICG 4746 & 5.0 & 6.0 & 5.5 & 3.3 & 3.0 & 3.2 \\
\hline ICG 6022 & 5.0 & 4.7 & 4.8 & 2.7 & 3.3 & 3.0 \\
\hline ICG 6993 & 4.7 & 5.0 & 4.8 & 3.3 & 2.7 & 3.0 \\
\hline ICG 11088 & 6.3 & 6.7 & 6.5 & 2.3 & 2.3 & 2.3 \\
\hline ICG 11426 & 3.0 & 4.0 & 3.5 & 2.0 & 2.0 & 2.0 \\
\hline Resistant check*** & 3.0 & 2.3 & 2.7 & 2.0 & 1.3 & 1.7 \\
\hline TMV 2 & 7.0 & 8.0 & 7.5 & 6.0 & 7.0 & 6.5 \\
\hline
\end{tabular}

*Accessions are categorized based on the mean resistance/susceptible reaction to rust and LLS diseases on a 1-9 scale

Resistant $(\mathrm{R})=1-3$; Moderately resistant $(\mathrm{MR})=4-5$; Susceptible $(\mathrm{S})=6-7$; Highly susceptible $(\mathrm{HS})=8-9$ disease

severity rating scale

*** ICGV 00068 for LLS and ICGV 00064 for rust are the resistant checks 
Fig. 4 Late leaf spot progress in selected peanut mini core accessions during 2012 rainy season at ICRISAT, Patancheru, India

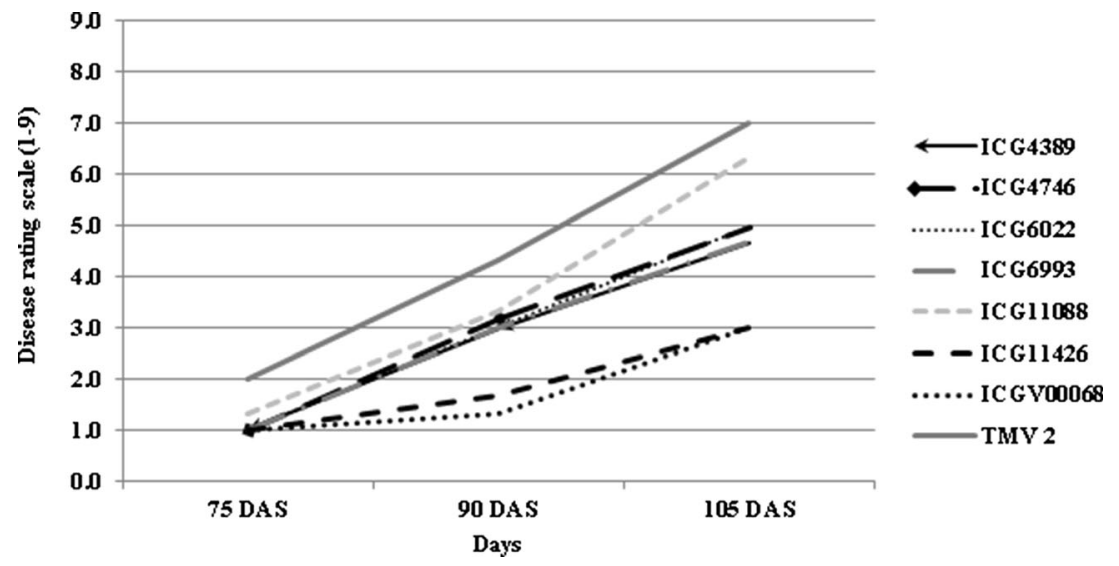

\section{Results}

Data analysis indicated no significant differences for pooled data with respect to year for both LLS and rust diseases. Significant genotypic variances for both LLS and rust diseases were observed during individual years as well as for pooled data $(p<0.01)$. Similarly, the variance due to genotype*environment interaction $\left(\sigma^{2}\right.$ ge) was significant for both LLS and rust diseases $(p<0.01)$. However, variance components due to genotypes $\left(\sigma^{2} \mathrm{~g}\right)$ were high compared to the genotype*environment interaction for both LLS and rust diseases (Table 1).

\section{Field evaluation of genotypes against late leaf spot (LLS) and rust diseases}

\section{Late leaf spot}

During 2012, out of 184 mini core accessions, two accessions (ICG 11426 and ICG 12625) showed resistance reaction. Further, 73 accessions were moderately resistant; 82 accessions were susceptible. About 27 accessions have shown highly susceptible reaction (Fig. 1). During 2013, a total of 41 accessions have shown moderately resistant reaction, whereas 94 accessions were susceptible and 49 accessions were highly susceptible (Fig. 2).

Analysis of pooled data for 2012 and 2013 experiments indicated that 53 accessions were moderately resistant (MR) to LLS (Table 2). The majority of accessions were susceptible (S) $(n=86)$, whereas 45 accessions were highly susceptible (HS). However, none of the accessions were completely resis$\operatorname{tant}(\mathrm{R})$ to LLS. The control, TMV 2 was rated 8, with a highly susceptible reaction. In LLS plots, 19 accessions yielded $>2500 \mathrm{~kg} \mathrm{ha}^{-1}$ and only two genotypes had $<500 \mathrm{~kg} \mathrm{ha}^{-1}$. Further, 86 accessions yielded between 1501 and $2000 \mathrm{~kg}$ $\mathrm{ha}^{-1}$, whereas 77 yielded between 501 and $1500 \mathrm{~kg} \mathrm{ha}^{-1}$ (Fig. 3).

\section{Rust}

During 2012, out of 184 mini core accessions, eleven accessions (ICGs 11426, 11088, 6022, 12625, 15419, 4389, 111, 4343, 4527, 4746, and 6993) have shown resistance reaction. Further, 102 accessions were MR; 71 accessions were susceptible. None of the accessions have shown highly $\mathrm{S}$ reaction (Fig. 1). During 2013, a total of 16 accessions (ICGs 11426,
Fig. 5 Late leaf spot progress in selected peanut mini core accessions during 2013 rainy season at ICRISAT, Patancheru, India

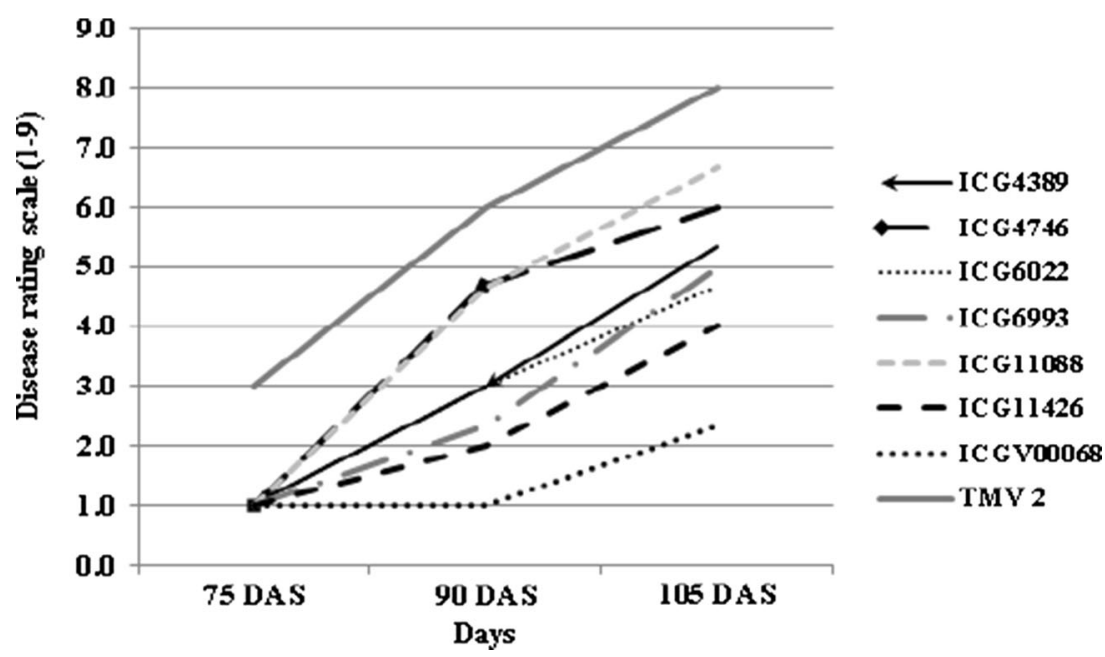


11088, 2857, 6402, 6993, 2925, 4389, 4746, 5051, 6646, $6766,10036,14127,2381,6022,7153)$ showed resistance reaction, 134 were moderately resistant, 34 accessions were susceptible. None of the accessions showed highly susceptible reaction (Fig. 2).

Analysis of pooled data for 2012 and 2013 experiments indicated that 10 accessions showed $\mathrm{R}$ reaction to rust. The majority of the accessions showed MR reaction $(n=115)$. Further, 59 lines were in the $\mathrm{S}$ category (Table 2). A disease severity scale of 8.0 (HS) was recorded for the susceptible cultivar TMV 2. In rust plots, only one accession (ICG 11426) has recorded a yield of $>2500 \mathrm{~kg} \mathrm{ha}^{-1}(2661 \mathrm{~kg}$ $\left.\mathrm{ha}^{-1}\right)$. The majority of the accessions $(n=165)$ have recorded yields in the range of 501-1500 kg ha ${ }^{-1}$. Only 15 accessions showed a yield level ranging from 1501 to $2500 \mathrm{~kg} \mathrm{ha}^{-1}$, whereas three accessions showed pod yields of $<500 \mathrm{~kg}$ ha $^{-1}$ (Fig. 3).

A few lines (six accessions: ICG 4389, ICG 6993, ICG 11426, ICG 4746, ICG 6022 and ICG 11088) with the lowest disease severity scores (for rust and LLS) were selected and their disease progress over time was plotted from the existing data. All these six accessions showed $\mathrm{R}$ reaction to rust in individual years. Of these, four accessions (ICGs' 4389, 6993, 11426 and 6022) showed MR reaction to LLS during individual years of assessment and their pooled mean (Table 3). Though, the other two accessions ICG 4746 and ICG 11088 showed S reaction to LLS, but exhibited superior yields (mean of 2012 and 2013 experiments) performance over other 'MR' accessions in LLS plots (data not shown), and hence were selected for further studies.

\section{Late leaf spot}

During both 2012 and 2013, the LLS disease severity was lowest with ICG 11426 and highest with ICG 11088 at 105
DAS (Table 3). All the remaining accessions were within the limits of resistant and susceptible controls that showed lowest and highest LLS progression respectively during both the years. There was more disease as the plants grew older, but this has more to do with the disease progress due to increase of inoculum rather than age of the plants (Figs. 4 and 5).

The yield levels varied among the selected accessions in LLS plots. The mean yields for 2012 and 2013 were highest with ICG 11426 (3715 $\mathrm{kg} \mathrm{ha}^{-1}$ ), followed by ICG 6022 (3430 $\mathrm{kg} \mathrm{ha}^{-1}$ ) and ICG $11088\left(3358 \mathrm{~kg} \mathrm{ha}^{-1}\right)$. No significant differences in yield were observed for ICG 11426 with that of resistant control ICGV 00068 (4148 $\left.\mathrm{kg} \mathrm{ha}^{-1}\right)$. However, the remaining five accessions produced significantly lower yield than the resistant control. The two susceptible accessions in LLS plots, ICG 6022 and ICG 11088 have also recorded higher yields (3430 and $3358 \mathrm{~kg} \mathrm{ha}^{-1}$, respectively) over the susceptible check (TMV 2). Lower yields were recorded with ICG 6993 (1058 $\left.\mathrm{kg} \mathrm{ha}^{-1}\right)$ and ICG 4389 (1569 $\left.\mathrm{kg} \mathrm{ha}^{-1}\right)$ and were comparable to those of the susceptible control TMV 2 (1306 kg ha ${ }^{-1}$ ) (Fig. 6).

\section{Rust}

During 2012 and 2013, the rust disease severity was lowest for ICG 11426 and ICG 11088 (Table 3). The disease progression was lowest with ICG 11426 and ICG 11088 at 75, 90 and 105 DAS, whereas it was highest in ICG 4746 and ICG 6993 during 2012 (Fig. 7). During 2013, it was highest in ICG 6022 at 105 DAS (Table 3 and Fig. 8). All the remaining accessions were within the limits of resistant and susceptible controls that showed lowest and highest LLS progression respectively. As the plants grew older, there was more disease, due to the increase in inoculum rather than the plant age (Figs. 7 and 8).
Fig. 6 Mean pod yield of selected peanut mini core accessions in late leaf spot (LLS) and rust screening plots calculated during 2012 and 2013 rainy seasons $\square$ LLS Rust

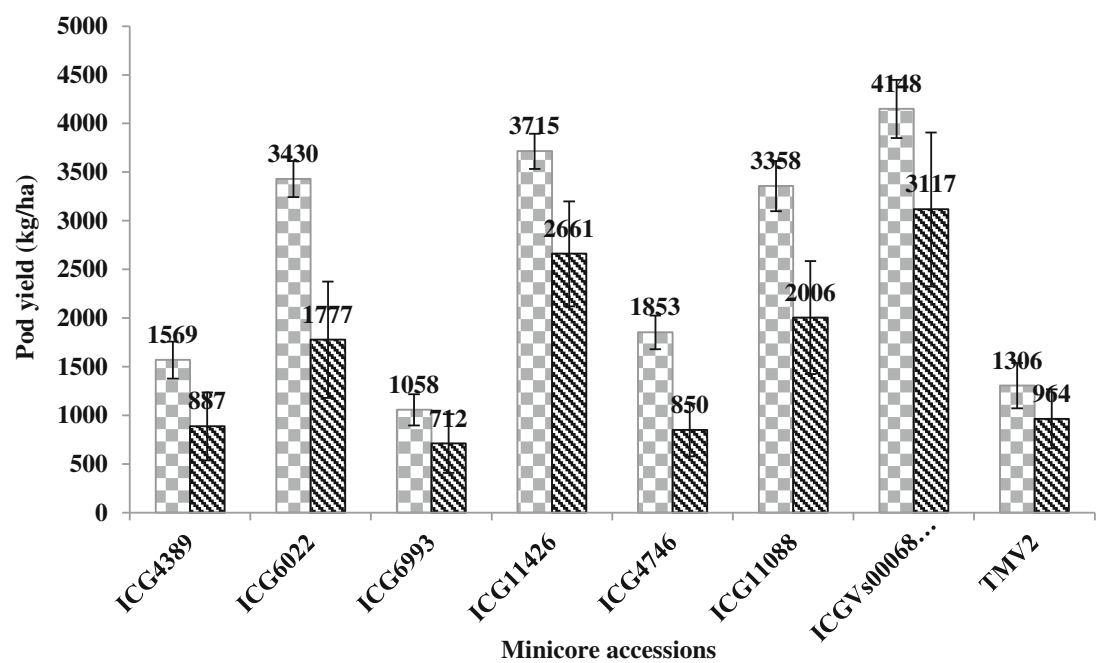


Fig. 7 Progress of rust disease in peanut fields during 2012 rainy season in selected peanut mini core accessions at ICRISAT, Patancheru, India

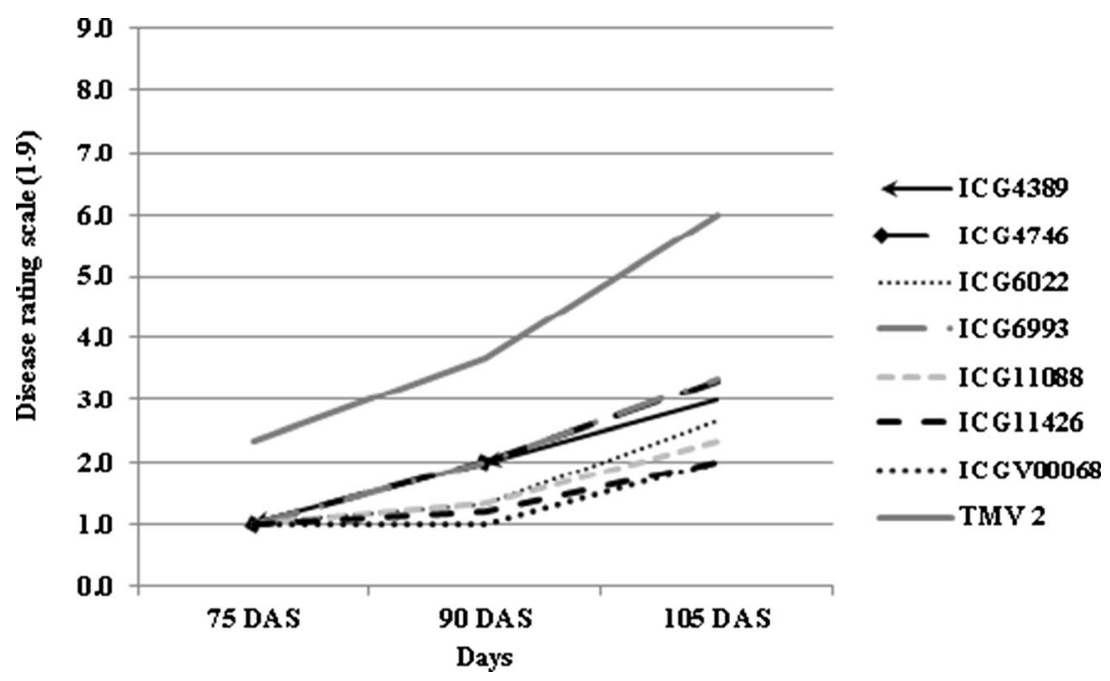

The mean yields for 2012 and 2013 also varied among the selected accessions in rust plots. Highest yield among accessions was recorded for ICG $11426\left(2661 \mathrm{~kg} \mathrm{ha}^{-1}\right)$, followed by ICG $11088\left(2006 \mathrm{~kg} \mathrm{ha}^{-1}\right)$ and ICG $6022\left(1777 \mathrm{~kg} \mathrm{ha}^{-1}\right)$. No significant differences in yield were observed for ICG 11426 with that of resistant control, ICGV $00064(3117 \mathrm{~kg}$ $\mathrm{ha}^{-1}$ ). The remaining five accessions however produced significantly lower yields than the resistant control. Lower yields were recorded for ICG $6993\left(712 \mathrm{~kg} \mathrm{ha}^{-1}\right)$, ICG $4746(850 \mathrm{~kg}$ $\left.\mathrm{ha}^{-1}\right)$ and ICG $4389\left(887 \mathrm{~kg} \mathrm{ha}^{-1}\right)$ with no significant differences with the susceptible control. TMV 2 had a yield of $964 \mathrm{~kg} \mathrm{ha}^{-1}$ (Fig. 6).

\section{Reaction of released cultivars to late leaf spot and rust}

All the cultivars (Gangapuri, ICGS 44, ICGS 76 and M 13) were found to be susceptible to LLS disease. For rust screening, ICGS 44, ICGS 76 and M 13 exhibited MR reaction, whereas Gangapuri recorded susceptible (S) reaction.

\section{Discussion}

Selection of resistant sources by thorough screening of mini core collection accessions is in practice for infusing genetic diversity in plant breeding programs (Upadhyaya et al. 2010). Mini core germplasm screening for identifying promising resistant sources for biotic and abiotic stresses (Vadez et al. 2007; Kashiwagi et al. 2007) has also been done in other crops. One of the advantages with mini core collection is its reduced size over core collection, and this provides more scope for systematic evaluation, for traits useful in crop improvement (Upadhyaya et al. 2010). Mini core collections of ICRISAT mandate crops such as peanut, pigeonpea and chickpea have become international public goods (IPGs) and are now being used by National Agricultural Research System (NARS) researchers in 20 countries. For example, in pigeonpea, sources of combined resistance to Fusarium wilt and sterility mosaic diseases (ICPs 6739, 8860, 11015, 13304 and 14819) were identified from the mini core collection (Sharma et al. 2012). Earlier studies indicated useful variation
Fig. 8 Progress of rust disease in peanut fields during 2013 rainy season in selected peanut mini core accessions at ICRISAT, Patancheru, India

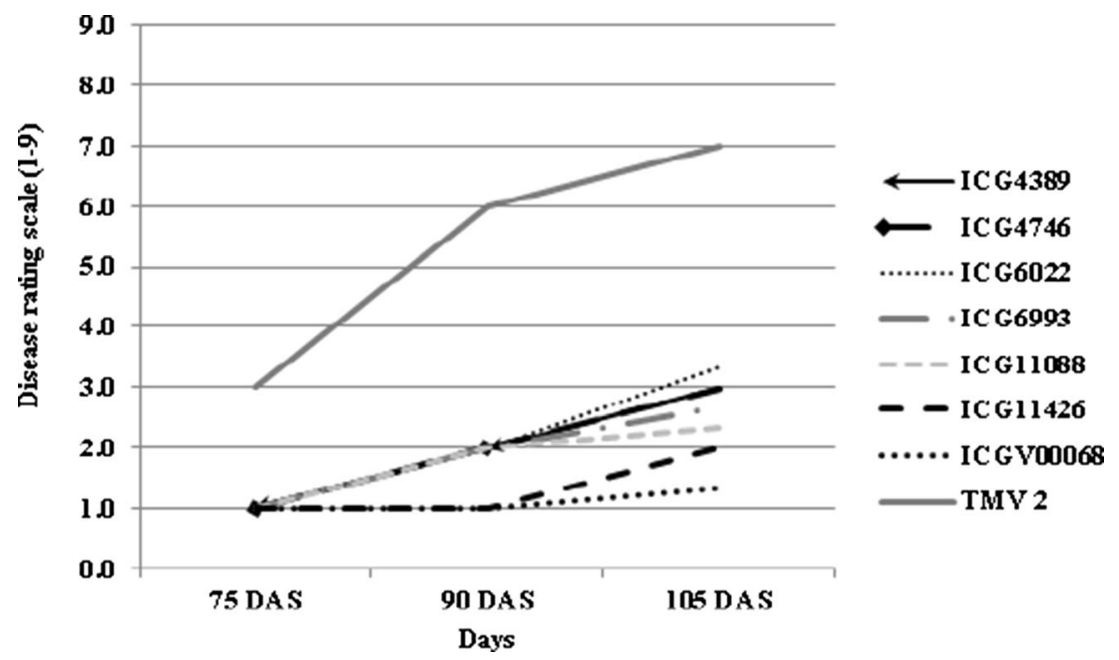


in mini core to various biotic and abiotic stresses as in chickpea (Kaul et al. 2005; Johnson et al. 2007).

In the present study, the selected peanut accessions (all are Arachis hypogaea) ICGs 4389 (Origin: India), 6993 (Origin: Brazil), 11426 (Origin: India), 6022 (Origin: Sudan), 4746 (Origin: Israel) and 11088 (Origin: Peru) showed superior reactions in terms of resistance, lower rates of LLS and rust disease progress and also good pod yields. These six mini core accessions can therefore be considered for infusing resistance for LLS and rust diseases in peanut. Detailed investigations should also be further carried out to determine the resistance levels of these accessions towards different components such as incubation period, latent period, sporulation, lesion size, plant appearance score and per cent necrotic area (Aquino et al. 1995). It has been reported that several components have been shown to negatively impact the rate of disease progression under field conditions (Foster et al. 1980; Ricker et al. 1985). For example, in case of early leaf spot (ELS) of peanut induced by Cercospora arachidicola, latent period (Foster et al. 1980) and the maximum percentage of sporulating lesions (Ricker et al. 1985) are the critical components for selecting the rate reducing resistance of ELS. For LLS, components of resistance have been investigated earlier (Nevill 1981; Pixeley et al. 1990; Shew et al. 1988; Subrahmanyam et al. 1982; Watson 1987). However, evaluating multiple components for these foliar diseases can be a tedious task due to various reasons (Aquino et al. 1995). Since, sporulation, latent period and lesion size are most critical components that determine the resistance of accessions to these diseases, critical investigations in these lines will be useful before recommending these selected accessions for resistance breeding programs on LLS and rust.

Acknowledgments Authors are thankful to CGIAR Consortium for providing financial support as this work has been undertaken as part of the CGIAR Research Program on Grain Legumes. ICRISAT is a member of CGIAR Consortium.

\section{References}

Abdou YAM, Gregory WC, Cooper WE (1974) Sources of resistance to Cercospora arachidicola Hori and Cercosporidium personatum (Berk. And Curt.) Deighton in Arachis species. Peanut Sci 1:6-11

Anderson WF, Holbrook CC, Brenneman TB (1993) Resistance to Cercosporidium personatum within peanut germplasm. Peanut Sci 20:53-57

Anderson WF, Holbrook CC, Culbreath AK (1996) Screening the peanut core collection for resistance to tomato spotted wilt virus. Peanut Sci 23:57-61

Aquino VM, Shokes FM, Gorbet DW, Nutter FW (1995) Late leaf spot progression on peanut as affected by components of partial resistance. Plant Dis 79:74-78

Arthur JC (1929) The Plant Rust (Uredinales). Wiley, New York, 446pp
Augusto J, Brenneman TB (2011) Implications of fungicide application timing and post-spray irrigation on disease control and peanut yield. Peanut Sci 38:48-56

Bayles RA, Flath K, Hovmoller MS, Pope CV (2000) Breakdown of the Yrl7 resistance to yellow rust of wheat in northern Europe. Agronomie 20:805-811

Biswas S, Singh NP (2005) Fungicidal management of foliar diseases of peanut in Tripura. Indian Phytopathol 58:500-502

Chamberlin KDC, Melouk HA, Payton ME (2010) Evaluation of the U.S. peanut mini core collection using a molecular marker for resistance to Sclerotinia minor Jagger. Euphytica 172:109-115

Chiteka ZA, Gorbet DW, Shokes FM, Kucharek TA, Knauft DA (1988) Components of resistance to late leaf spot in peanut. I. Levels and variability-Implications for selection. Peanut Sci 15:25-30

Clark E, Backman PA, Rodriguez-Kabana R (1974) Cercospora and Cercosporidium tolerance to benomyl and related fungicides in Alabama peanut fields. Phytopathology 64:1476-1477

Cook M (1972) Screening for resistance to peanut rust in the greenhouse and field. Plant Dis Rep 56:382-386

Culbreath AK, Stevenson KL, Brenneman TB (2002) Management of late leaf spot of peanut with benomyl and chlorothalonil: a study in preserving fungicidal utility. Plant Dis 86:349-355

El-Jarroudi M, Giraud F, Tychon B, Hoffmann L, Delfosse P (2011) First report of the breakdown of the $\mathrm{Yr} 17$ resistance gene to wheat stripe rust in the Grand-Duchy of Luxembourg. J Plant Pathol 93:243

Felix S, Ricaud C (1977) Occurrence and fungicidal control of peanut rust in Mauritius. Revue Agric Sucr Ile Maurice 56:110-114

Foster DJ, Beute MK, Wynne JC (1980) Spore production and latent period as mechanisms of resistance to Cercospora arachidicola in four peanut genotypes. Peanut Sci 7:88-90

Gibbons RW (1980) Peanut improvement research technology for semiarid tropics. In: Proceedings of the International Symposium on Development and Transfer of Technology for Rainfed Agriculture and the Sat Farmer. ICRISAT (International Crops Research Institute for the Semi-Arid Tropics), Patancheru, pp 27-37

Gorbet DW, Norden AJ, Shokes FM, Knauft DA (1987) Registration of 'southern runner' peanut. Crop Sci 27:817

Gorbet DW, Knauft DA, Shokes FM (1990) Response of peanut genotypes with different levels of leaf spot resistance to fungicide treatments. Crop Sci 30:529-533

Grichar WJ, Besler BA, Jaks AJ (1998) Peanut (Arachis hypogaea L.) cultivar response to leaf spot disease development under four disease management programs. Peanut Sci 25:35-39

Gupta SK, Gupta PO, Parashar RD, Sindhan GS (1987) Fungicidal control of leaf spots and influence on quality of peanut. Indian Phytopathol 40:360-364

Gupta SK, Gupta PP, Yadava TP (1988) Estimation of oil content by wide line NMR. Oil Crops Newsl 5:15-16

Harrison AL (1969) Control of rust and Cercospora leaf spot of peanuts in south Texas. Phytopathology 62:803

Holbrook CC, Dong W (2005) Development and evaluation of a mini core collection for the US peanut germplasm collection. Crop Sci 45:1540-1544

Hossain MH, Hossain I (2013) In vitro studies of some selected botanicals and Bau-biofungicide on mycelial growth and conidial germination of Cercospora arachidicola and Cercosporidium personatum. Int $\mathrm{J}$ Agric Res Innov Technol (IJARIT) 3:36-40

Johnson PL, Sharma RN, Nair SK, Pandey RL, Kashyap OP (2007) Study of genetic diversity in chickpea under rainfed situation. In: Abstracts: national Symposium on Legumes for Ecological Sustainability-Emerging Challenges and Opportunities. IIPR, Kanpur, pp 199

Kashiwagi J, Krishnamurthy L, Upadhyaya HD, Singh S (2007) Identification of high-yielding and large-seeded kabuli chickpeas with drought avoidance root traits. SAT e-J 3:1-2 
Kaul J, Kumar S, Gurha SN (2005) Evaluation of exotic germplasm of kabuli chickpea. Indian J Plant Genet Resour 18:201-204

Kishore GK, Pande S (2005) Integrated management of late leaf spot (C. personata) and rust diseases of peanut (Arachis hypogaea) with Prosopis juliflora leaf extract. Int J Pest Manag 51:325-332

Knauft DA, Gorbet DW (1989) Genetic diversity among peanut cultivars. Crop Sci 29:1417-1422

Kornegay JL, Beute MK, Wynne JC (1980) Inheritance of resistance to Cercospora arachidicola and Cercosporidium personatum in six Virginia-type peanut lines. Peanut Sci 7:4-9

Littrell RH (1974) Tolerance in Cercospora arachidicola to benomyl and related fungicides. Phytopathology 64:1377-1378

Maiti MK, Raj SK, Dey S (2005) Management of leaf spot (Cercospora arachidicola and $C$. personata) of peanut by seed treatment with non-conventional chemicals. Indian J Agric Sci 75:452-453

McDonald D, Subrahmanyam P, Gibbons RW, Smith DH (1985) Early and late leaf spots of peanut, Information Bulletin no. 21. International Crops Research Institute for the Semi-Arid Tropics, Patancheru

Mehan VK, Reddy PM, Vidyasagar Rao K, McDonald D (1994) Components of rust resistance in peanut genotypes. Phytopathology 84:1421-1426

Mehan VK, Reddy PM, Subrahmanyam P, McDonald D, Singh AK (1996) Identification of new sources of resistance to rust and late leaf spot in peanut. Int J Pest Manag 42:267-271

Miller IL, Norden AJ, Knauft DA, Gorbet DW (1990) Influence of maturity and fruit yield on susceptibility of peanut to Cercosporidium personatum (late leaf spot pathogen). Peanut Sci 17:52-58

Naidu PH, Vasanthi RP (1995) Influence of sowing dates on Tikka leaf spot in rabi and summer peanut (Arachis hypogaea L.). Legum Res 25:275-281

Natrajan S (1984) Fungicidal control of rust and tikka leaf spot of peanut. Pesticides 18:40-41

Nevill DJ (1981) Components of resistance to Cercospora arachidicola and Cercospora personatum in peanuts. Ann Appl Biol 99:77-86

Nigam SN, Dwivedi SL, Rao YLC, Gibbons RW (1990) Registration of ICGV 87128 peanut cultivar. Crop Sci 30:959

Nigam SN, Dwivedi SL, Rao YLC, Gibbons RW (1991) Registration of 'ICGV 87141' peanut. Crop Sci 31:1096

Pensuk V, Patanothai A, Jogloy S, Wongkaew S, Akkasaeng C, Vorasoot N (2003) Reaction of peanut cultivars to late leaf spot and rust. Songklanakarin J Sci Technol 25:289-295

Pixeley KV, Boote KJ, Shokes FM, Gorbet DW (1990) Growth and partitioning characteristics of four peanut genotypes differing in resistance to late leaf spot. Crop Sci 30:796-804

Porter DM, Smith DH, Rodriguez-Kabana R (1982) Peanut diseases. In: Pattee HE, Young CT (eds) Peanut Science and Technology. American Peanut Research and Education Society, Inc., Yoakum, pp 326-340

Ricker MD, Beute MK, Campbell CL (1985) Components of resistance in peanut to Cercospora arachidicola. Plant Dis 69:1059-1064

SAS Institute Inc (2013) SAS/STAT ${ }^{\circledR} 12.3$ User's Guide. Cary, NC

Savary S, Van Santen G (1992) Effect of crop age on primary gradients of late leaf spot (Cercosporidium personatum) on peanut. Plant Pathol 41:265-273

Sharma M, Rathore A, Naga Mangala U, Ghosh R, Sharma S, Upadhyaya HD, Pande S (2012) New sources of resistance to Fusarium wilt and sterility mosaic disease in a mini core collection of pigeonpea germplasm. Eur J Plant Pathol 133:707-714

Shew BB, Beute MK, Wynne JC (1988) Effects of temperature and relative humidity on expression of resistance to Cercosporidium personatum in peanut. Phytopathology 78:493-498
Shokes FM, Gorbet DW, Sanden GF (1982) Effect of planting date and date of spray initiation on control of peanut leaf spots in Florida. Plant Dis 66:574-575

Singh AK, Mehan VK, Nigam SN (1997) Sources of resistance to peanut fungal and bacterial diseases: An update and appraisal, Information Bulletin no. 50. International Crops Research Institute for the SemiArid Tropics, Patancheru, 48 pp

Smith DH, Littrell RH (1980) Management of peanut foliar diseases with fungicides. Plant Dis 64:356-361

Souta FW (1912) Report on the prevalence of some pests and diseases in the West Indies for 1910 \& 1911. West Indian Bull 12:432

Subrahmanyam P, McDonald D (1983) Rust disease of peanut. ICRISAT Information Bulletin No. 13

Subrahmanyam P, Mehan VK, Nevill DJ, McDonald D (1980) Research on fungal diseases of peanut at ICRISAT. In: Gibbons RW (ed) Proc. of International Workshop on Peanut. ICRISAT, Patancheru, pp 193-198

Subrahmanyam P, Mc Donald D, Gibbons RW, Nigam SM, Nevill DJ (1982) Resistance to rust and late leaf spot diseases in some genotypes of Arachis hypogaea. Peanut Sci 9:6-10

Subrahmanyam P, Reddy LJ, Gibbons RW, McDonald D (1985) Peanut rust: a major threat to peanut production in the semiarid tropics. Plant Dis 69:813-819

Subrahmanyam P, Rao VR, McDonald D, Moss JP, Gibbons RW (1989) Origins of resistance to rust and late leaf spot in peanut (Arachis hypogaea Fabaceae). Econ Bot 43:444-455

Subrahmanyam P, Mc Donald D, Waliyar F, Reddy LJ, Nigam SN (1995) Screening methods and sources of resistance to rust and late leaf spot of peanut, Information Bulletin No. 47. ICRISAT, Patancheru, p 19

Upadhyaya HD (2005) Variability for drought resistance related traits in the mini core collection of peanut. Crop Sci 45:1432-1440

Upadhyaya HD, Bramel PJ, Ortiz R, Singh S (2002) Developing a mini core of peanut for utilization of genetic resources. Crop Sci 42: $2150-2156$

Upadhyaya HD, Ortiz R, Bramel PJ, Singh S (2003) Development of a peanut core collection using taxonomical, geographical and morphological descriptors. Genet Resour Crop Evol 50:139-148

Upadhyaya HD, Yadav D, Dronavalli N, Gowda CLL, Singh S (2010) Mini core germplasm collections for infusing genetic diversity in plant breeding programs. Electron J Plant Breed 1:1294-1309

Vadez V, Krishnamurthy L, Serraj R, Gaur PM, Upadhyaya HD, Hoisington DA, Varshney RK, Turner NC, Siddique KHM (2007) Large variation in salinity tolerance in chickpea is explained by differences in sensitivity at reproductive stage. Field Crops Res 104:123-129

Waliyar F (1991) Evaluation of yield losses due to peanut leaf diseases in West Africa, Summary proceedings of the second ICRISAT regional peanut meeting for West Africa, 11-14 September 1990. ICRISAT Sahelian Centre, Niamey, Niger. ICRISAT (International Crops Research Institute for the Semi-arid Tropics), Patancheru, pp 32-33

Waliyar F, McDonald D, Subba Rao PV, Reddy PM (1993) Components of resistance to an Indian source of Cercospora arachidicola in selected peanut lines. Peanut Sci 20:93-96

Watson GR (1987) Levels and components of resistance to late leaf spot caused by Cercosporidium personatum (Berk. \& Curt.) Deighton in the peanut Arachis hypogaea (L.) genotypes Florunner, Southern Runner, and UF81206. Ph.D. diss, University of Florida, Gainesville

Zhou L, Huo C, Liu J, Liu Z (1980) Studies on peanut rust in Guangdong Province. Acta Phytophylacica Sin 7:65-74 (in Chinese with English summary) 